\title{
BIOSORPTION OF Cu (II) METAL IONS BY DRAGON FRUIT SKIN (Hylocereus polyrhizus)
}

\author{
Sahriani Ali ${ }^{1 *}$, Nursiah La Nafie ${ }^{1}$, Paulina Taba ${ }^{1}$ \\ ${ }^{1}$ Department of Chemistry FMIPA Hasanuddin University Tamalanrea Makassar 90425
}

\begin{abstract}
Abstrak. Biosorpsi merupakan metode yang efektif untuk menghilangkan ion logam berat dari suatu larutan. Biosorpsi ion logam $\mathrm{Cu}$ (II) dengan menggunakan biosorben kulit buah naga pada variasi waktu kontak, pH dan konsentrasi telah diteliti. Konsentrasi ion $\mathrm{Cu}(\mathrm{II})$ sebelum dan setelah adsorpsi ditentukan dengan menggunakan Spektrofotometer Serapan Atom (SSA). Pengaruh pH dalam proses biosorpsi dipelajari pada $\mathrm{pH}$ 2-7. Hasil penelitian menunjukkan bahwa waktu optimum biosorpsi ion $\mathrm{Cu}$ (II) biomassa kulit buah naga adalah 10 menit dan $\mathrm{pH}$ optimum biosorpsi adalah 4. Model Langmuir dan Freundlich digunakan untuk mempelajari isotermal adsorpsi. Dari hasil penelitian ini, diperoleh informasi bahwa biosorpsi ion logam $\mathrm{Cu}$ (II) dengan menggunakan kulit buah naga lebih sesuai dengan model isotermal Langmuir dibandingkan isotermal Freundlich dengan kapasitas adsorpsi (Qo) 20,401 mg/g biosorben. Hasil analisis FT-IR menunjukkan bahwa gugus hidroksil yang berperan dalam pengikatan ion $\mathrm{Cu}(\mathrm{II})$.
\end{abstract}

Kata Kunci : Biosorpsi, SSA, Isotermal Langmuir, ion Cu(II), Kulit Buah Naga.

Abstract. Biosorption is an effective method for removal of heavy metals from their solutions. Biosorption of $\mathrm{Cu}$ (II) by contact time, $\mathrm{pH}$, and concentration has been investigated. Concentration of $\mathrm{Cu}$ (II) ion before and after adsorption was determined using Atomic Absorption Spectrophotometer (AAS). The effect of the $\mathrm{pH}$ process was studied at $\mathrm{pH}$ of 2-7. The result showed that the optimum time for biosorption of $\mathrm{Cu}$ (II) ion by biomass dragon fruit was 10 minutes and $\mathrm{pH} 4$ was the optimum $\mathrm{pH}$ of biosorption. Langmuir and Freundlich models were used for the adsorption of isotherm. Result showed that biosorption of $\mathrm{Cu}$ (II) by dragon fruit peel fit better the Langmuir model than Freundich model with the adsorption capacity $\left(\mathrm{Q}_{\mathrm{o})}\right.$ of $20.401 \mathrm{mg} / \mathrm{g}$ biosorbent. The result of FT-IR analysis showed that hydroxyl groups were responsible for the binding of $\mathrm{Cu}$ (II) ions.

Keywords: Biosorption, AAS, Langmuir Isotherm, Ion $\mathrm{Cu}$ (II), Dragon Fruit Peel. 


\section{INTRODUCTION}

Environmental pollution is an increasingly important problem to solve because it involves the safety, health, and life of living things. Among the many problems of environmental pollution at this time that get serious attention is the problem of environmental pollution caused by heavy metals. This pollution can cause large losses, because generally the waste/waste in the environment contains toxic substances, one of which is $\mathrm{Cu}$ (Darmono, 2001).

$\mathrm{Cu}$ metals in the aquatic environment can be separated in various ways, such as the way of coating, filtering, settling, and flooding of suspended particles. However, this method is considered to be less effective because it requires relatively high costs, high production of toxic waste sludge and can complicate the handling process and disposal. For that absorption method is used by using materials that are relatively inexpensive, can be obtained easily and have high absorption (Zein et al., 2003 in Lelifajri, 2010).

One alternative in processing wastes containing heavy metals is the use of biological materials as adsorbents. This process is then referred to as biosorption. Biosorption shows the ability of biomass to bind heavy metals from the solution through metabolic or chemical and physical steps. The advantages of using the biosorption process include relatively low costs, minimal sludge formation, and easy regeneration processes (Ashraf et al., 2010).
The biosorption process is influenced by contact time, $\mathrm{pH}$ and concentration (Kuraisy, 2008). In addition, the finalprocess was biosorptioncarried out by determining the amount of biosorption capacity adsorbed by metal ions using an isothermal adsorption approach. Common isothermal adsorption is used, namely Freundlich isothermal and Langmuir isothermal (Hawari et al., 2006).

Biological materials that can be used as raw materials for biosorbents are waste from agricultural products. Waste of agricultural products is organic waste which is certainly very easy to find in large quantities. The use and use of agricultural waste as raw materials for biosorbents in addition to helping reduce the volume of waste can also empower waste to become a product that has a selling value. Therefore, the potential of agricultural waste is large enough to be used as raw material for biosorbent of heavy metals (Kurniasari, 2010).

Various biosorbents using agricultural or biological materials have been carried out by previous researchers such as biosorption using pineapple leaves (Budiyanto et al., 2010), Bali orange peel (Tasaso, 2014), and sawdust powder (Lelifajri, 2010)

Components which plays a role in the heavy metal adsorption process with adsorbents of biological materials is the active group present in the material. The groups that will attract and bind metals in biomass, groups-groups that include hydroxyl and carboxyl (Ahalya et al., 
2003).

One waste that contains many active groups is the dragon fruit skin. From the analysis results show that dragon fruit skin contains nitrogen, carbon, hydrogen, and sulfur (Mallampati, 2013). The compounds contained in dragon fruit peel containgroups $-\mathrm{OH}$ and $-\mathrm{COOH}$. The active groups when viewed from HSAB (Hard Soft Acid Base) are classified as hard bases while $\mathrm{Cu}$ (II) metals are categorized as intermediate acids, so $\mathrm{Cu}$ (II) can interact well with the active groups found in dragon fruit skin (Lin et al ., 2002). Namal et al. (2013) have succeeded in conducting research using dragon fruit skin to adsorb Mn (II) ions. This shows that dragon fruit skin has the potential to be used as biosorbent of heavy metal ions (Mallampati, 2013).

Based on the description, the study utilizing dragon fruit skin as biosorbent was carried out for removal of heavy metals $\mathrm{Cu}^{2+}$.

\section{MATERIALS AND METHODS}

\section{Materials}

The materials used in this study is the dragon fruit leather, crystal $\mathrm{Cu}$ $\left(\mathrm{NO}_{3}\right)_{2} .3 \mathrm{H}_{2} \mathrm{O}, \quad \mathrm{HNO}_{3}, \quad \mathrm{NaOH}$, distilled water, akuabides,filter Whatman 42paper,label paper, and tissue roll.

\section{Equipments}

Equipment used in this study were commonly used glassware, sieves (passed 100sieves mesh and did not pass 230sieves mesh), SPNISOSFD model ovens,stirrers, magneticdigital balance Ohaus models NO AP210, crushers, pH meters, spray bottles, a set ofdevices centrifuge, a set of SSA tools, a set of FT-IR spectrophotometer devices SHIMADZU 8201 models of PCs and desiccators.

\section{PROCEDURE}

\section{Dragon Fruit Biosorbent \\ Preparation (Hylocereus polyrhizus)}

Dragon fruit skin is cut into small pieces, then washed with running water to remove dirt. Then the dragon fruit skin is rinsed with distilled water, and drained. Dragon fruit skin is dried in the sun for 1 week. Furthermore, dragon fruit skin is dried in the oven at $80^{\circ} \mathrm{C}$ for 24 hours. Then the dragon fruit skin is stored in the desiccator. After that, the dragon fruit skin was crushed / crushed using a crusher, and sieved with a size of 100filter mesh but did not pass the 230filter mesh.

\section{Determination of Optimum} Biosorption Time of $\mathrm{Cu}$ (II) By Dragon Fruit Skin (Hylocereus polyrhizus)

Dragon fruit skin powder is weighed as much as 0.2 grams and put in $100 \mathrm{~mL}$ erlenmeyer. Then $50 \mathrm{~mL}$ of $\mathrm{Cu}$ (II) solution with a concentration of $100 \mathrm{ppm}$ was added. The mixture is shaken with a magnetic stirrer for 5 minutes and filtered. Filtrate absorbance was measured by Atomic Absorption Spectrophotometer at a wavelength of $324.8 \mathrm{~nm}$. The experiment is then repeated with a time 
variation of $10 ; 15 ; 20 ; 30 ; 40 ; 50 ; 60 ; 70$; 80; and 90 minutes. Each experiment was repeated two times. The blank experiment was carried out as above but without shaking with a magnetic stirrer.

\section{Determination of $\mathbf{p H}$ Effect of $\mathrm{Cu}$} (II) Ion Biosorption by Dragon Fruit Skin (Hylocereus polyrhizus)

As much as 0.2 grams of dragon fruit skin powder is put into a $100 \mathrm{~mL}$ erlenmeyer glass containing $50 \mathrm{~mL}$ of $\mathrm{Cu}$ (II) $100 \mathrm{ppm}$ solution. Then shaken with a magnetic stirrer with variations in $\mathrm{pH} 2$, 3, 4, 5, 6 and 7 during optimum contact time. Filtered withfilter paper. WhatmanFiltrate 42absorbance was measured by Atomic Absorption Spectrophotometer.

\section{Determination of $\mathrm{Cu}$ (II) Ion Biosorption Capacity by Dragon Fruit Skin (Hylocereus polyrhizus)}

Dragon fruit skin powder is weighed as much as 0.2 grams and put in $100 \mathrm{~mL}$ erlenmeyer containing $50 \mathrm{~mL}$ of $\mathrm{Cu}$ (II) solution with a concentration variation of $50 ; 100 ; 150 ; 250$ and $400 \mathrm{ppm}$. The mixture is shaken with a magnetic stirrer during optimum time and $\mathrm{pH}$ and then filtered. The residue was analyzed by FT-
IR and the filtrate was analyzed by SSA.

\section{Analysis of FTIR}

Analysis of FTIR spectrum (Fourier Transform Infra Red) was carried out on dragon fruit skin biomass before and after adsorption. The spectra were recorded at the 4000-400 cmwave number area ${ }^{-1}$ with a resolution of $4 \mathrm{~cm}^{-1}$ at room temperature using the DTGS detector (Deuterated Triglycine Sulphate). Spectra is processed using Easy Plot Software.

\section{RESULTS AND \\ DISCUSSION}

Optimum Biosorption of Cu (II) Ion with Dragon Fruit Skin (Hylocereus polyrhizus)

The amount of $\mathrm{Cu}$ (II) ions adsorbed at 5 minutes is $5.001 \mathrm{mg} / \mathrm{g}$. This amount increases at stirring time of 10 minutes until it reaches the optimum limit with an adsorbed ion amount of $5.27 \mathrm{mg} / \mathrm{g}$. After exceeding the optimum time in 10 minutes, the amount of adsorbed $\mathrm{Cu}$ (II) ions tends to decrease from 30 minutes to 90 minutes. This data shows that the active side of the surface of the dragon fruit skin is saturated. The amount of $\mathrm{Cu}$ (II) ions adsorbed as a function of time is shown in Figure 4. 


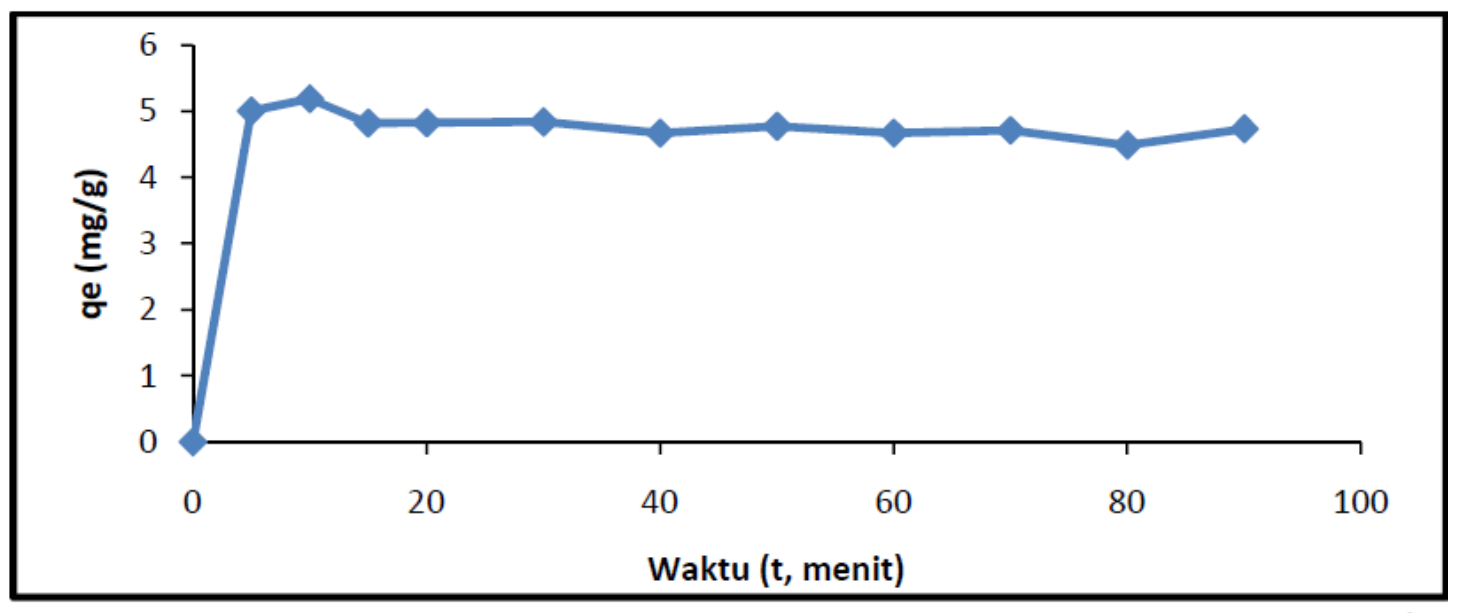

Figure 4. Amount of $\mathrm{Cu}$ (II) ions adsorbed vs. contact time with biosorbent of dragon fruit skin $(\mathrm{Co}=100 \mathrm{ppm}, \mathrm{pH}=5.1)$.

This is in accordance with the theory which states that the longer the time used more and more dissolved substances are adsorbed. However, the amount of dissolved

For further research, time used by $\mathrm{Cu}$ (II) ions by fruit peels The dragon is at the 10 minute time is the optimum time.

\section{Effect of pH on the biosorption Ion $\mathrm{Cu}$ (II)} By Skin dragon fruit(Hylocereus polyrhizus)

Effect of $\mathrm{pH}$ on ion biosorption $\mathrm{Cu}$ (II) by dragon fruit skin is carried out between $\mathrm{pH}$ solute will reach the maximum limit, because the biosorbent surface has been covered by adsorbed Cu (II) ions (Kuraisy,2008).

2 to $\mathrm{pH} 7$ with time stirring during optimum time 10 minutes. Determination of the influence of $\mathrm{pH}$ from biosorption of $\mathrm{Cu}$ (II) ions by skin biosorbents dragon fruit is determined by counting the number of ions adsorbed (Qe) at various $\mathrm{pH}$. Results of ion biosorption studies $\mathrm{Cu}$ (II) is shown in Figure 5.

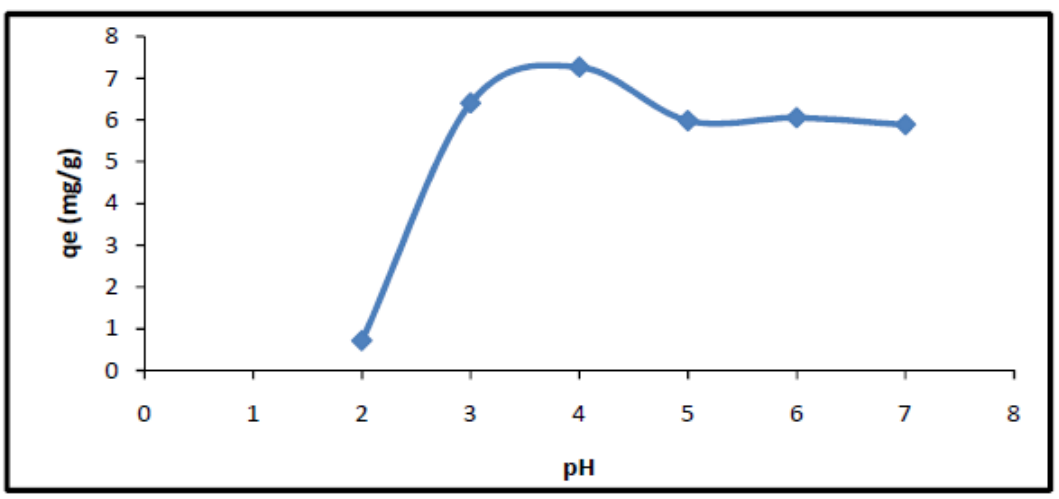

Figure 5. Amount of $\mathrm{Cu}$ (II) Ions adsorbed by Dragon Fruit Skin vs. $\mathrm{pH}(\mathrm{t}=10$ minutes, $\mathrm{Co}=100 \mathrm{ppm})$. 
The amount of $\mathrm{Cu}$ (II) ions adsorbed by dragon fruit skin at $\mathrm{pH} 2$ is $0.72 \mathrm{mg} / \mathrm{g}$. This amount increases and reaches a maximum at $\mathrm{pH} 4$ with adsorbed amount to $7.27 \mathrm{mg} / \mathrm{g}$. After passing $\mathrm{pH} 4$ the amount adsorbed tends to decrease.

According to Pravasant, et al., (2005) the low number of $\mathrm{Cu}$ (II) ions adsorbed at low $\mathrm{pH}$ is because the solution containsH+ high concentrations ofions so that $\mathrm{Cu}$ (II) ions compete with protons in interaction with the active side on the biosorbent surface. At low $\mathrm{pH}$, the biosorbent surface is covered by Hions+ which prevent $\mathrm{Cu}$ (II) ions from approaching the biosorbent surface because of the repulsive force.

With increasing $\mathrm{pH}$, the concentration of Hions+ decreases and the surface of the adsorbent becomes more negative so that $\mathrm{Cu}$ (II) ions will be more easily adsorbed. At a higher $\mathrm{pH}$ which is $\mathrm{pH} 5$ and 6 the amount of $\mathrm{Cu}$ (II) ions adsorbed decreases and then tends to be constant up to $\mathrm{pH} 7$. A decrease in the amount of metal ions absorbed in the adsorption process at high $\mathrm{pH}$ occurs before reaching the $\mathrm{pH}$ where the metal ion settling is caused by the formation of dissolved hydroxyl complexes of metal ions so that metal ions can no longer bind to the active groups the adsorbent (Ahmad et al., 2009). From the data above the optimum $\mathrm{pH}$ to adsorb $\mathrm{Cu}$ (II) metal ions by dragon fruit skin is $\mathrm{pH} 4$.

This is similar to that reported by Tasaso (2014) on biosorption of $\mathrm{Cu}$ (II) ions by grapefruit skin which is optimum at $\mathrm{pH} 4$, as Gulnaz et al. (2005) reported on biosorption of $\mathrm{Cu}$ (II) ions by sludge dry active, Tikupadang (2009) also reported the optimum $\mathrm{pH}$ of biosorption of $\mathrm{Cu}$ (II) ions by sago pulp at $\mathrm{pH}$ 4. Subsequent studies were carried out at $\mathrm{pH} 4$.

\section{Capacity ion biosorption of $\mathrm{Cu}$ (II) with skin dragon fruit (Hylocereuspolyrhizus)}

Total $\mathrm{Cu}$ (II) adsorbed by the skin of the dragon fruit as a function of the initial concentration of $\mathrm{Cu}$ (II) is given in Figure 6. the amount of $\mathrm{Cu}$ (II) adsorbed increases with increasing initial concentration. In the concentration range used, the amount of $\mathrm{Cu}$ (II) ion adsorbed continues to increase which means the adsorbent has not saturated. Therefore the determination of adsorption capacity was carried out using Langmuir and Freundlich isotherms. Figures 7 and 8 show Langmuir and Freundlich isotherms. 


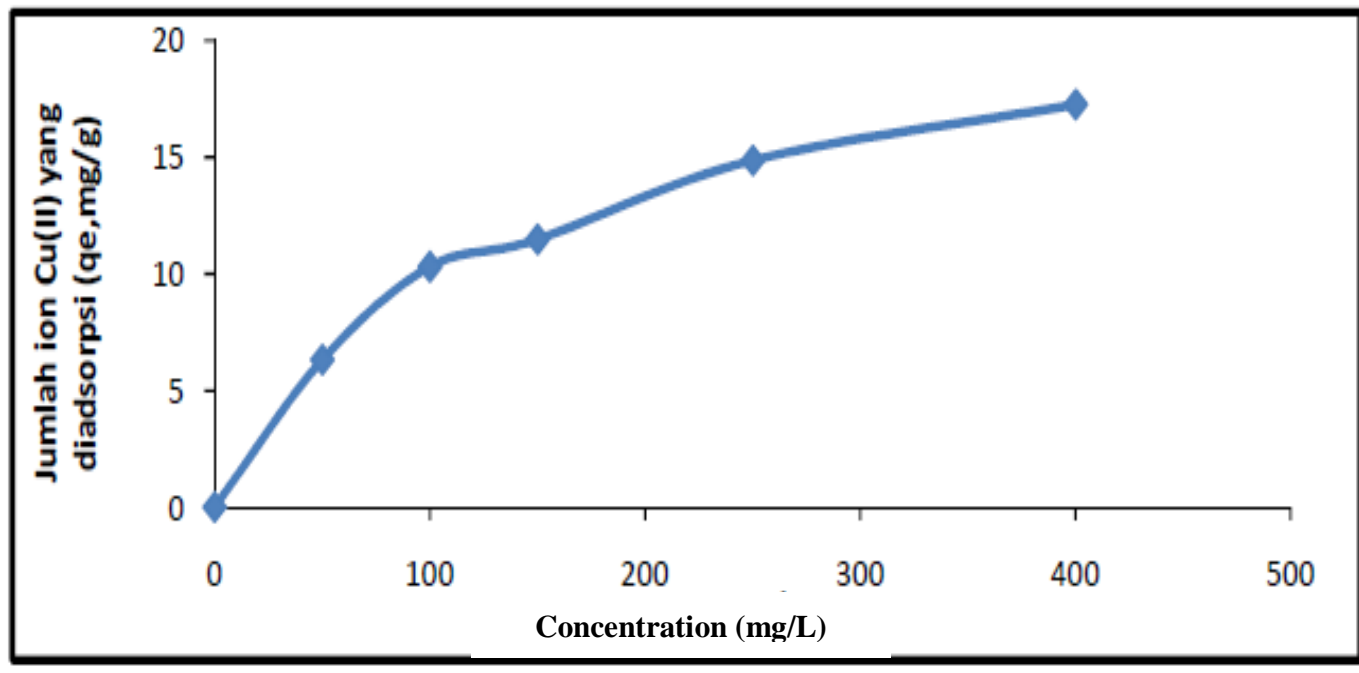

Figure 6. Amount of $\mathrm{Cu}$ (II) ions adsorbed by dragon fruit skin vs. $\mathrm{Cu}$ (II) ion concentration in solution after adsorption $(\mathrm{t}=10$ minutes, $\mathrm{pH}=4)$

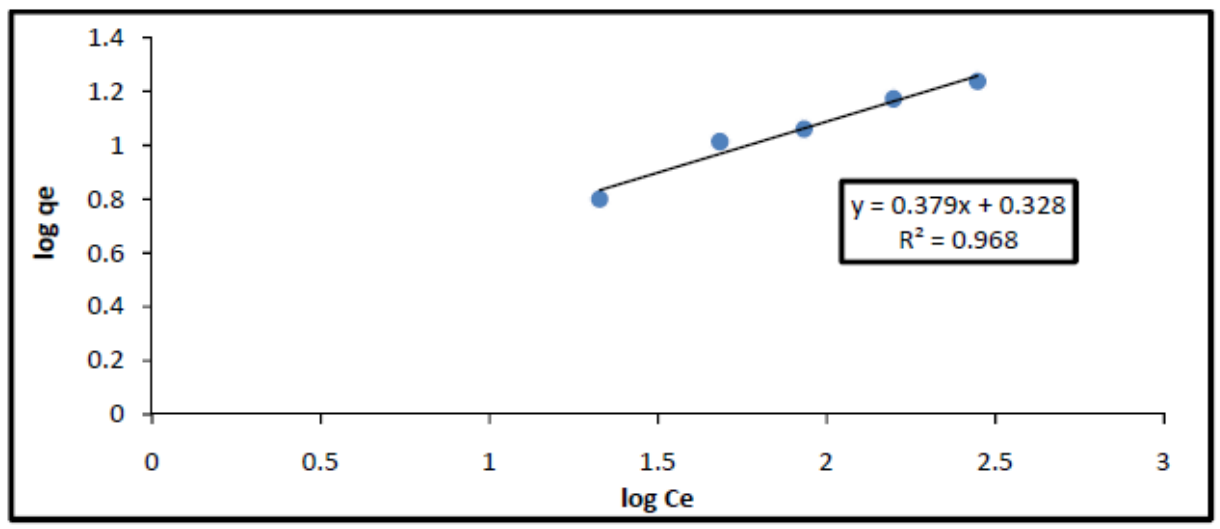

Figure 7. Langmuir isotherm with variations in concentration of $50 \mathrm{mg} / \mathrm{L}, 100 \mathrm{mg} / \mathrm{L}, 150 \mathrm{mg} / \mathrm{L}$ $250 \mathrm{mg} / \mathrm{L}, 400 \mathrm{mg} / \mathrm{L}$ at $\mathrm{pH} 4$.

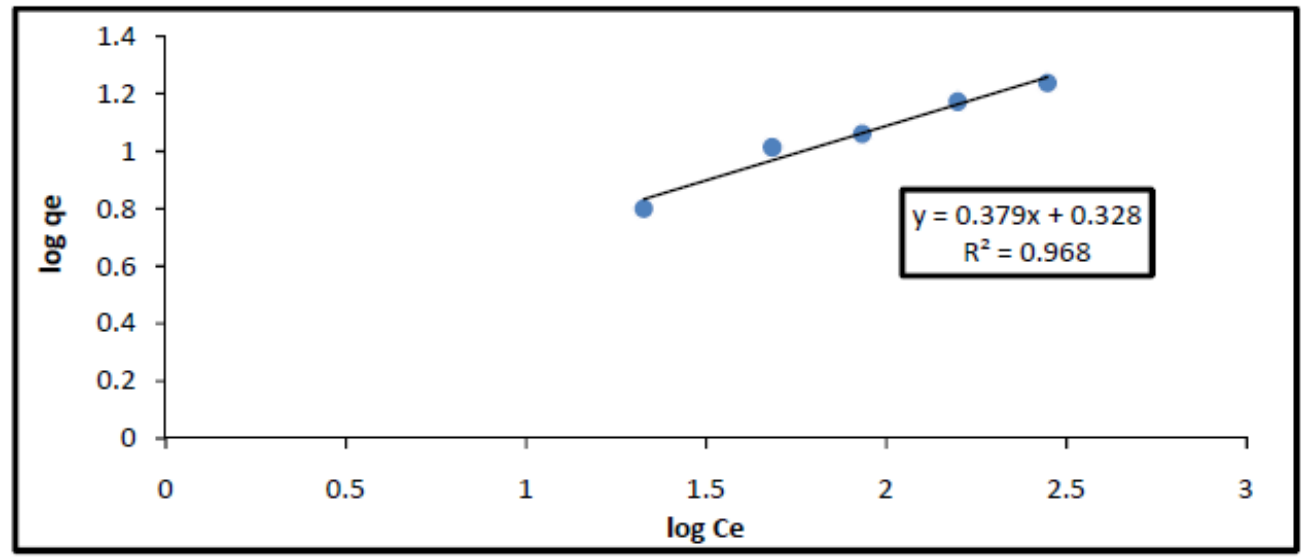

Figure 8. Freundlich isotherm with varying concentrations of $50 \mathrm{mg} / \mathrm{L}, 100 \mathrm{mg} / \mathrm{L}, 150 \mathrm{mg} / \mathrm{L}$, $250 \mathrm{mg} / \mathrm{L}, 400 \mathrm{mg} / \mathrm{L}$ at $\mathrm{pH} 4$. 
By comparing line values least square, the model will be selected suitable isothermal adsorption. Figure 7 and 8 shows that ion adsorption $\mathrm{Cu}$ (II) on dragon fruit skin is more suitable where is Langmuir isothermal adsorption where the point tends to indicate a straight line relationship according to value least square where R2 is obtained (0.995), whereas in isothermal adsorption Freundlich obtained R2 of 0.968. Intercept and isothermal slope from adsorption Langmuir provides capacity value biosorption (Qo) of $20.401 \mathrm{mg} / \mathrm{g}$ or $0.321 \mathrm{mmol} / \mathrm{g}$ and $\mathrm{b}$ (biosorption intensity) amounting to $0.02 \mathrm{~L} / \mathrm{mg}$.

Tikupadang (2009) shows that biosorption of $\mathrm{Cu}$ (II) ions by sago pulp also according to Langmuir isothermal with a value of Qo $=10.92 \mathrm{mg} / \mathrm{g}$. The thing that the same was reported by Moo (2010) who use tofu dregs as biosorbent $\mathrm{Cu}$ (II) ion with a value of $\mathrm{Qo}=$ $7.91 \mathrm{mg} / \mathrm{g}$. Septiany (2008) shows that biosorption of $\mathrm{Cu}$ (II) ions by rhizome biomass T. hemprichii is in accordance with isothermal Langmuir with a Qo value of $37.03 \mathrm{mg} / \mathrm{g}$. But Lesage et al. (2006) show that biosorption of $\mathrm{Cu}$ (II) ions by the plant Myriophyllum spicatum L. according to Freundlich's isotherm with $\mathrm{k}=29 \mathrm{mg} / \mathrm{g}$. According to Kojima and Lee (2001) in Pravasant, et al.,(2005), different adsorbents provide different adsorption characteristics. Therefore, compatibility of isothermal adsorption depends on the biosorbent used.

\section{Results of FT-IR Analysis of FT-IR}

FT-IR spectrum of dragon fruit skin before and after biosorption can be seen in Figure 9. Some of the peaks detected in the sample prior to biosorption as in the sample $1056.99 \mathrm{~cm}^{-1}$ (stretched CO), $1643.35 \mathrm{~cm}^{-1}$ (stretched C = O), $2922.16 \mathrm{~cm}^{-1}$ (stretching $\mathrm{CH}$ aliphatic) and $3415.93 \mathrm{~cm}^{-1}$ (stretching $\mathrm{OH})$. The peaks were also observed in the spectrum after biosorption except the peak at $3415.93 \mathrm{cmstretch}^{-1}$ ( $\left.-\mathrm{OH}\right)$ experienced a shift to $3442.94 \mathrm{~cm}^{-1}$. This shows the interaction of $\mathrm{Cu}$ (II) ions with hydroxyl groups contained in dragon fruit skin. In addition, in the regions, the wave $524.64 \mathrm{~cm}^{-1}$ also experienced a shift to $534.26 \mathrm{~cm}^{-1}$. This absorption peak shift is caused by the bond between $\mathrm{Cu}$ (II) and oxygen (Cu-O strain) (Gatial et al., 2014).

Based on the results of FT-IR analysis, interactions are expected to occur between hydroxyl $(-\mathrm{OH})$ groups derived from lignin and cellulose with $\mathrm{Cu}$ (II) ions due to the presence of hydroxyl $(-\mathrm{OH})$ groups in cellulose and lignin which are not impeded by transient steric effects on pectin, the hydroxyl group is blocked by the presence of steric effects and also the group $(-\mathrm{OH})$ in the pectin that comes from the group $(-\mathrm{COOH})$, oxygen in the group $(-\mathrm{OH})$ and group (-CO) has the same ability to draw electrons because of the conjugate effect so the possibility of shifting is the group (-CO). 


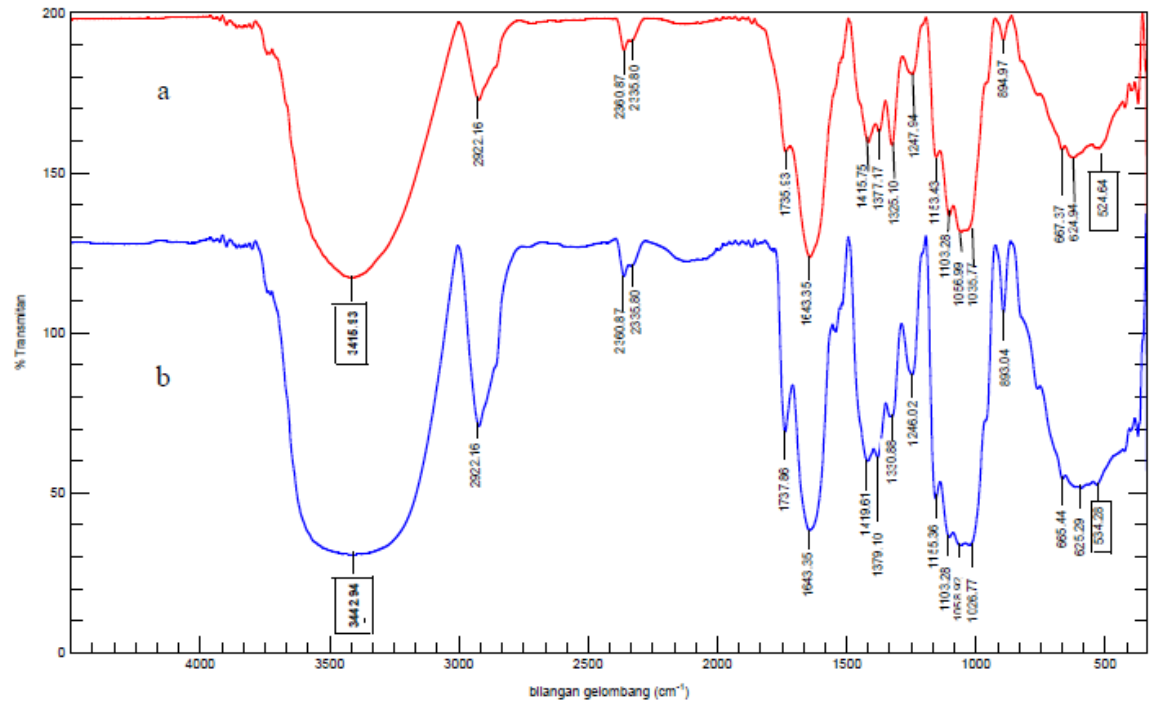

$3500300025^{2.16}$

Figure 9. Spectrum Analysis Results of FT-IR Dragon Skin Biosorbents (a) Before Contacting with Ions of $\mathrm{Cu}$ (II) and (b) After Contact with Metals $\mathrm{Cu}$ (II)

Figures 10 and 11 show the difference in bond energy in the group hydroxyl $(-\mathrm{OH})_{1}$ is the lignin blocked by steric and group $(-\mathrm{OH})$ effects 2 which is not blocked by the steric effect. Difference this bond energy indicates that the group which tends to bind to ions $\mathrm{Cu}$ (II) is group $(-\mathrm{OH})_{2}$ which is not blocked by steric effects. Cluster $(-\mathrm{OH})_{2}$ the smaller the energy of the bond tends to be more stable and from the structure of the group $(-\mathrm{OH})_{2}$ is more free than cluster $(\mathrm{OH})_{1}$ which is blocked by the effect steric. The proposed reaction is given to Figure 12.

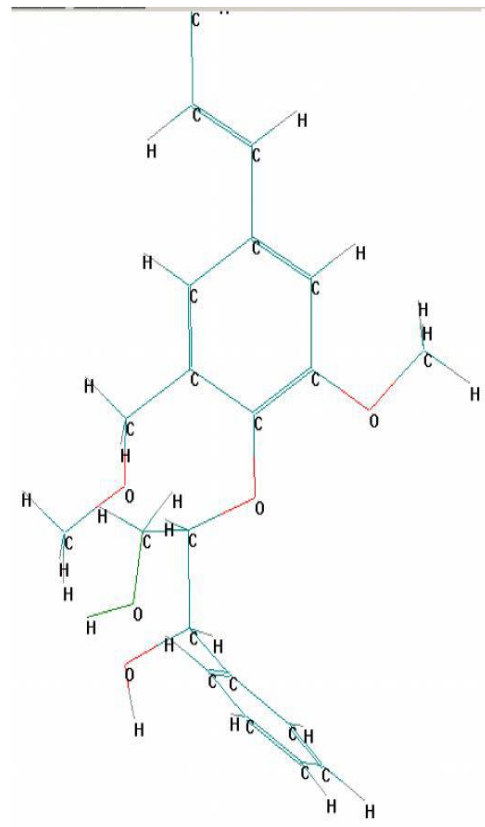

Figure 10. The Hydroxyl Group (-OH) which is blocked by the steric effect of group $(-\mathrm{OH})_{1}$ is blocked by effects steric. Total Energy $=104.602 \mathrm{kcal} / \mathrm{mol}$

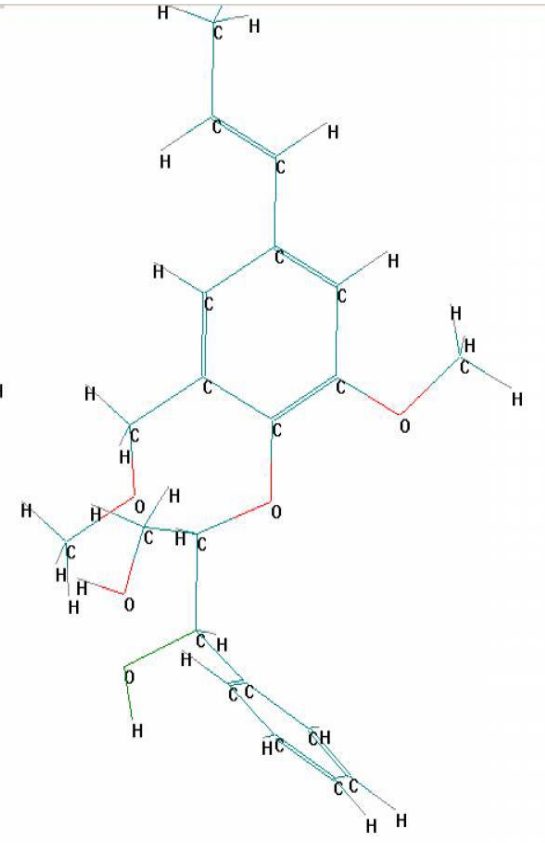

Figure 11. The Hydroxyl $(-\mathrm{OH})$ group which is not blocked by the steric effect Total Energy $=74,029 \mathrm{kcal} / \mathrm{mol}$ 


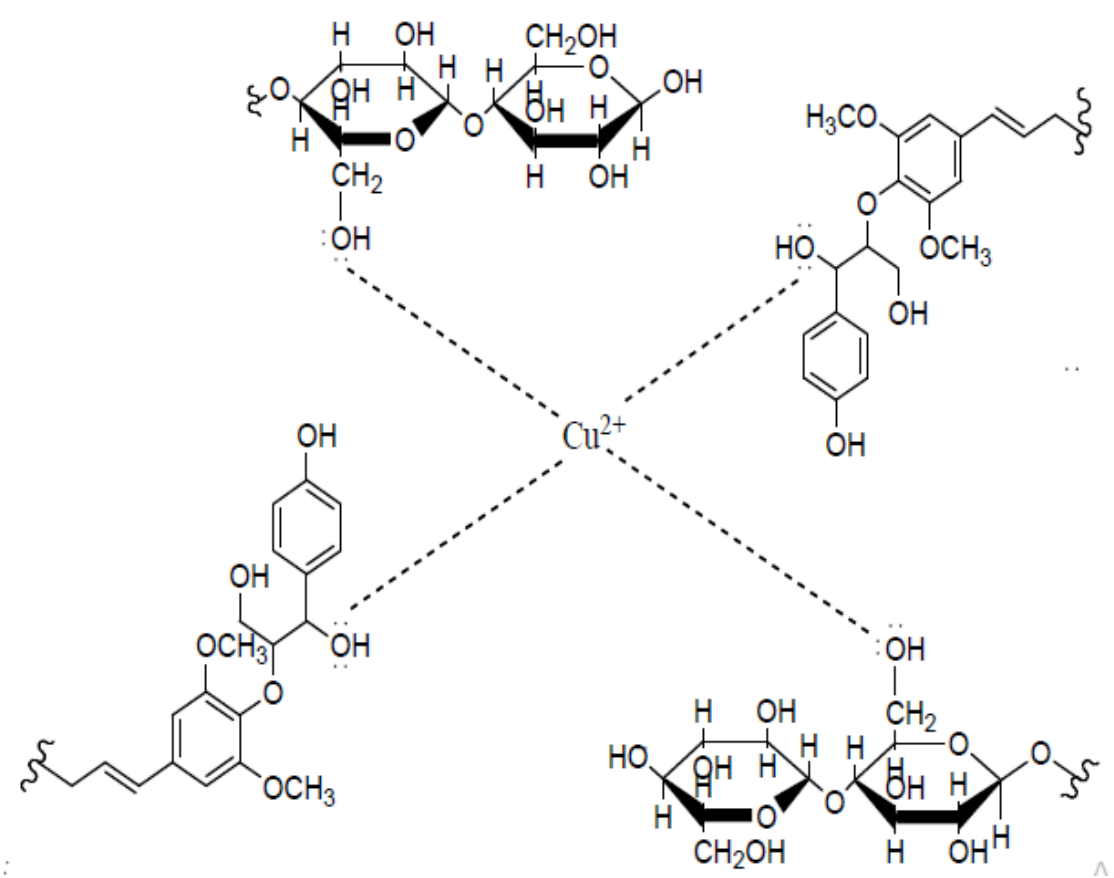

Figure 12. the reaction between $\mathrm{Cu}$ (II) with a group of lignin and cellulose

\section{CONCLUSION}

The optimum time biosorption $\mathrm{Cu}$ (II) by the skin of the dragon fruit is 10 minutes, with the optimum $\mathrm{pH}$ is 4 . ion biosorption of $\mathrm{Cu}$ (II) by the skin of the dragon fruit meet with

\section{REFERENCES}

Ahalya, N., Ramachandra, TV, and Kanamadi, RD., 2003, Biosorption of Heavy Metal, Research J. Chem. Environ., 7(4): 71-79.

Ahmad, A., Rafatullal, M., Sulaiman, O., Ibrahim, MH, Chii, YY, and Siddique, $\mathrm{BM}, 2009$, Removal of $\mathrm{Cu}$ (II) and $\mathrm{Pb}$ (II) ions from solutions by adsorption on sawdust of Meranti wood, Desalination, 250: 300- 310.

Ashraf, MA, Maah, MJ, and Yusoff, I., 2010, Study of Banana peel (Musa sapientum) as a Cationic Biosorben, AmericanEurasia, J. Agric. Enviro. Sci., 8(1): 7-17. Budiyanto, E., Wardani, AY, and Nirmala, W., 2010, Utilization of Pineapple Leaves (Ananas comosus) as $\mathrm{Ag}$ and $\mathrm{Cu}$ the Langmuir isothermal Qvalue of 20.401 $\mathrm{mg} / \mathrm{g}$ or $0.321 \mathrm{mmol} / \mathrm{g}$. The functional group involved in biosorption of $\mathrm{Cu}$ (II) ions by dragon fruit peel namely hydroxyl group $(-\mathrm{OH})$.

Metal Adsorbents in Kotagede Silver Industry Waste, Unpublished Thesis, Department of Chemistry FMIPA UNY, Yogyakarta

Darmono, 2001, Environment and Pollution of Relationships with Toxicology of Metal Compounds, UI-Press. Jakarta.

Gatial, A., Mudra, M., Moncol, J., Dankova, M., Peter, L., and Breza Martin., 2014, Structure and Vibrational Spectra of copper (II) pyridylmethanolate tetrahydrate, Chemical Papers, 68( 7): 940-949.

Gulnaz, O., Saygideger, S., and Kusvuran, E., 2005, Study of $\mathrm{Cu}$ (II) Biosorption by Dried Activated Sludge: Effect of the Physico-Chemical Environment and Kinetics Study, J. Hazard . Matt., B120, 193-200. 
Hawari, AH, and Catherine NM, 2006, Biosorption of Lead (II), Cadmium (II), Copper (II) and Nickel (II) by Anaerobic Granular Biomass. Bioresource Technal, 97: 692-700.

Kuraisy, A., 2008,Biosorbent, Unpublished Utilization of Rhizoma of Seagrass Rhizoma thallasia hemprichii which is on Barrang Lompo Island as Ion Cu (II) Thesis, Department of Chemistry FMIPA UNHAS, Makassar.

Kurniasari, L., 2010, "Utilization of Microorganisms and Agricultural Waste asRaw Heavy Metal BiosorbentMaterials"Magazine Scientific, Faculty of Engineering, Wahid Hasyim University Semarang, Moment Journal, 6(2): 5-8

Lelifajri, 2010, Adsorption of $\mathrm{Cu}$ Metal Ions (II ) Using Lignin from Saw Wood Powder Waste, Journal of Chemical and Environmental Engineering , 7(3): 126129.

Lesage, E., et al., 2006, Sorption of Co, Cu, $\mathrm{Ni}$ and $\mathrm{Zn}$ from Industrial effluents by the submerged aquatic macrophyte Myriophyllum spicatum L., Ecol Eng, 30, 32-325.

Lin, YE, Vidic, RD, Stout, JE and Yu, VL, 2002, Negative Effect of High $\mathrm{pH}$ on Biocidal Efficacy of Copper and Siver Ions in Cotrolling Legionella pneumophila, AEM, 68(6): 2711-2715

Mallampati, R. , 2013, Biomimetic Synthesis Of Hydrid Materials For Potential Applications, A Thesis Submitted For The Degree Of Doctor Of Philosophy, Department Of Chemistry National University Of Singapore, Singapore.

Moo, BW, 2010, Cu (II) Metal Biosorption by Using Tofu DregsUnpublishedThesis, Department of Chemistry FMIPA UNHAS, Makassar.

Namal, P., Linda BI Lim, Dahri, MK, and Tennakoon, DTB, 2013, Dragon Fruit Skin as a Potential Low-cost Biosorbent for Removal of Manganese (II) Ions, 2013, 8(3): 178-188 .

Pravasant, P., Apiratikul, R., Sungkhum, V., Suthiparinyanont, P., Wattanachira, S., and Marhaba, TF, 2005, Biosorption of $\mathrm{Cu}^{2+}, \mathrm{Cd}^{2+}, \mathrm{Pb}^{2+}$, and $\mathrm{Zn}{ }^{2+}$ using dried marine green macro algae Caulerpa lentillifera. Biores. Technol.

Septiany, I., 2008, Utilization of Thallasia hemprichii Rhizoma Seagrass Biomass on Barrang Lompo Island as Ion Cu (II) Biosorbent, Unpublished Thesis, Department of Chemistry FMIPA UNHAS, Makassar.

Tasaso, P., 2014, Adsorption of Copper Using Pomelo Peel and Depectinated Pomelo Peel, J. Clean. Energy. Technol., 2(2): 154-157.

Tikupadang, LJ, 2009, Biosorption of Cu (II) Metal Ions by Sago DregsUnpublishedThesis, Department of Chemistry FMIPA UNHAS, Makassar. 